JMKSP (Jurnal Manajemen, Kepemimpinan, dan Supervisi Pendidikan)

Volume 7 Issue 1 (2022) Page 337-352

ISSN 2614-8021 (Online) 2548-7094 (Print)

\title{
Mapping the Quality of Soft and Hard Skills of Industrial Internships Using Importance Performance Index and Customer Satisfaction Index
}

\section{Ganjar Ndaru Ikhtiagung ${ }^{1}$, Faidzin Firdhaus ${ }^{1}$, Costantein Imanuel Sarapil ${ }^{2}$ \\ ${ }^{1}$ Politeknik Negeri Cilacap, ${ }^{2}$ Politeknik Negeri Nusa Utara Corresponding Author E-mail: ganjar@pnc.ac.id}

Received 17 December 2021; Revised 15 January 2022; Accepted 8 March 2022

\begin{abstract}
Industrial internships are a means for students to gain work experience while at the same time understanding the organizational environment and solving problems in the company/industry. This study aims to map the quality of soft skills and hard skills to the satisfaction of companies/industries where students carry out Industrial Internships, to get the results of mapping the quality of soft skills and hard skills the methods used are Importance-Performance Analysis (IPA) and Customer Satisfaction Index (CSI). The object of research used in this study is the population of Industrial Internship students in 2021, amounting to 110 students. The questions used in the questionnaire use a range of 1-7 where the company/industry conducts an assessment by filling out a statement question questionnaire where the distance is 3 months, the distance is the ideal distance for stakeholders in assessing the quality of students' soft skills and hard skills. The implication of the research results from the mapping of soft skills and hard skills of Industrial internships students is that the attributes contained in quadrant A consist of soft skills: self-confidence, motivation, and adaptability. And hard skills: Proficient in maintaining work tools, Learning Speed to use new work tools, and Ability to provide opinions, are attributes that need to be considered by the Department of Electronic Engineering to maintain company/industry trust to continue to accept the Industrial Internship program.
\end{abstract}

Keywords: Industrial internships, Soft Skill, Hard Skill, Importance-Performance Analysis (IPA), Customer Satisfaction Index (CSI) 


\section{Introduction}

Apprenticeship is the most effective performance-based learning activity program to introduce students to the world of work. At the Cilacap State Polytechnic (PNC), an internship or better known as Industrial Apprenticeship is a field practice learning activity that is carried out outside campus or in industry. Industrial Internships are part of the PNC curriculum system which refers to production-based education (production base education) which aims to equip students with the ability to adapt to an industrial environment. In addition, the characteristics of the learning process at PNC are vocational education, so that in the teaching process more emphasis is placed on two approaches, namely practice with a percentage of $60 \%$ and theory $40 \%$ (Cilacap State Polytechnic, 2017).

According to Zhao \& Wang (2020) internship is an effort to further introduce the field of work and responsibilities to students before entering the world of work. In addition to being part of the curriculum series or in the Academic process, Industrial Internships are directed to integrate on-campus learning with work competencies required by the industry as well as a part of Out Come Base Education (OBE) or achievement-based learning at PNC (Cilacap State Polytechnic, 2017). To obtain objective evaluation results from the implementation of the Industrial Internship for Cilacap State Polytechnic students in the Electronics Engineering department, a method is needed that can describe the overall performance of students in the place of the Industrial Internship. The evaluation method is more focused on the performance results of soft skills and hard skills.

Soft skills according to Ronnie (2006) are a simple form of emotional intelligence that can be said as sensitive to recognizing and managing one's feelings (self-awareness) and others (Empathy). While the opinion of Elfindri, et al. (2011) that soft skills are defined as skills and life skills, both for oneself, in groups, or society, as well as a relationship with the Creator. Having good soft skills will make one's existence more felt in the community (Asbari, et al., 2020). So that a person's soft skills will be felt positively by other people or in individual communities, if the individual has communication skills, emotional control, language, and group skills, has ethics and morals, is polite and spiritual skills (Elfindri, et al., 2011).

Based on some opinions from the experts above, it can be interpreted that the soft skills of Industrial Internship students are skills possessed by students in establishing working relationships with employees and leaders in the Industrial 
environment (Interpersonal Skills) and skills in managing themselves (Intrapersonal skills) in carrying out their duties. maximum performance. The indicators for the soft skills of Industrial Internship students are Confidence, Accuracy, Ability to receive input and orders and advice (feedback), High motivation, Ability to be mature (initiative, commitment, and flexibility), Ability to adapt, Discipline, Honesty, and Have the ability to learn from mistakes.

According to Bahrumsyah (2010) as quoted by Widayanti (2012) hard skills are mastery of science, technology, and technical skills related to the field of science. Hard skill is a person's ability to master science and technology as well as other technical skills in developing Intelligence Quotient (IQ) related to the field of work (Patacsil \& Tablatin, 2017). While the opinion of Zulkifli, et al., (2018) is that hard skills are assignments of technical skills from learning outcomes related to certain fields of science. So from the above opinion that hard skills are not related to other people's skills because hard skills are more oriented to the development of one's Intelligence Quotient (IQ).

Referring to the opinions of experts and the explanations in the paragraph above, it can be explained that the Hard Skills possessed by Industrial Internship students are the mastery of science, technology, and technical skills inherent in supporting competence. The indicators for the hard skills of Industrial Internship students used in this study include Proficient in using work tools, Proficient in maintaining work tools, Able to carry out work procedures, Ability to explain engineering fields, Have engineering knowledge, Speed of learning to use work tools and Ability to provide opinions or answers in the field of Electronics/Electrical Engineering. If you look at the relationship between soft skills and hard skills in Industrial Internship students, then both have their proportions in supporting the success of graduates in the world of work. This is in line with the opinion of Ariwibowo \& Sailah (2008) which says that the role of hard skills for graduates in higher education is around $20 \%$, furthermore, it is said that students must have mastery and knowledge competencies as well as technology (hard skills), but must be able to communicate, work together in groups, work independently and be able to think analytically (soft skills) (Ariwibowo \& Sailah, 2008). Thus, the purpose of this study is to determine the extent of the soft skills and hard skills possessed by PNC Industrial Engineering students from the Department of Electronics Engineering from the perspective of Industrial satisfaction where students carry out Industrial Internship activities. 


\section{Literature Review}

The research conducted by Priyono, et al. (2021) has concluded that hard skills are a person's behavior, skills, and knowledge, which can be directly seen in the learning process. Learning outcomes will be easily defined, easily seen from an object of work tools. Meanwhile, according to the results of research by Illah (2008), soft skills are a person's ability that is superficial, where the results of actions cannot be seen directly, and have a strong relationship with a person's personal and interpersonal abilities. Furthermore, from the research findings of Illah (2008) where the role of hard skills on the success of university graduates is only about $20 \%$. For this reason, in addition to university graduates, they must have competence in mastering science and technology (hard skills), communication skills, working in teams, and analytical thinking (soft skills). If we look at the relationship between Soft Skills and Hard Skills of Industrial Internship students, both have their proportions in supporting the success of PNC graduates in the World of Work. In addition, from the explanation of Priyono, et al. (2021) and Illah (2008) that soft skills and hard skills have a relationship as the ability to internalize knowledge, attitudes, skills, competencies obtained in the learning process which is then accumulated through the experience of Industrial Magistrates.

\section{Methods}

The conceptual model used to measure stakeholder interest in the quality of soft skills and hard skills of Industrial Manganese students in the Electronics Engineering department is expected to provide feedback in the efforts of the Politeknik Negeri Cilacap to improve the quality of graduates. To determine the quality of the soft skills and hard skills of Industrial Internship students in the study using the Important and Performance Analysis (IPA) method. IPA is a tool to analyze the quality of services/products by comparing the performance perceived by the user to the desired level of satisfaction (Ikhtiagung \& Puspitasari, 2017). Meanwhile, according to Yola \& Budianto (2013) that the level of conformity is a comparison between the implementation performance score and the importance score so that the level of conformity will determine the priority to be used in handling or repairing. To get an idea of the quality of soft skills and hard skills, stakeholders in this case the industry/company/where students carry out Industrial Internships will conduct an assessment by filling out a statement question questionnaire with a distance of three months, this distance is 
the ideal distance for stakeholders in providing perspective assessments of the quality of soft skills and hard skills of Industrial Internship students.

In the questionnaire, the need value can be grouped into two, namely the strong attribute category group and the weak attribute value group. Furthermore, groups that have strong attributes will be mapped into the Cartesian quadrant, so that it can be seen whether the quality of the soft skills and hard skills of Industrial Internships students is as expected by stakeholders. The measurement scale used in this study uses the Linkert scale, where the level of the ordinal measure has been widely used in social research, especially to measure interests and perceptions (Singarimbun \& Effendi, 1987). The questions used in the Important Performance Analysis questionnaire range from 1-7, with the lowest score being 1 which means Strongly Disagree and the highest score being 7 which means Strongly Agree. The object of research used in this research is the population of Industrial Internship students in 2021 who come from the Electrical Engineering and Electronic Engineering Study Program, totaling 110 students.

The analytical technique used in this research is frequency \& descriptive, which in this analysis will describe the gap between interests/expectations/priorities and performance/stakeholder satisfaction or the industry where Electronic Engineering students carry out Industrial Internships. According to Aritonan (2005), to determine the level of stakeholder satisfaction, gap analysis, Cartesian diagrams, and the Customer Satisfaction Index (CSI) are used to analyze the overall level of satisfaction and per-variable, by performing the following steps:

The first step is to determine the Mean Importance Score (MIS). This value is derived from the average interest of each consumer

$$
M I S=\frac{\left(\sum_{\mathbf{i}=l}^{n} Y i\right)}{\mathbf{n}}
$$

The second step is to calculate the Weight Factor (WF). Where this weight is the percentage of the MIS value per service to the total MIS of all services.

$$
W F=\frac{M I S i}{\sum_{i=\mathbf{l}}^{p} M I S i} \times 100 \%
$$

The third step is to calculate the Weight Score (WS). This weight is the multiplication between WF and the average level of satisfaction (X) (Mean Satisfaction $=$ MSS)

$W S i=W F i \mathbf{x} M S s$ 
The fourth step, determine the Customer Satisfaction Index (CSI)

$$
C S I=\frac{\sum_{i=1}^{p} W S i}{H S} \times 100 \%
$$

In general, if the CSI value is above $80 \%$, it can be said that the stakeholders, in this case, the industry where students carry out Industrial Internships, are satisfied, but on the contrary, if the CSI value is below $80 \%$, the stakeholders cannot be said to be satisfied with the quality of the soft skills and hard skills of students. Industrial Internship. The scoring criteria above follow the Customer Satisfaction Index, where the CSI score is divided into seven criteria ranging from Very Poor to Excellent

Table 1. Customer Satisfaction Index Value Criteria

\begin{tabular}{ll}
\hline \multicolumn{1}{c}{ Index Value } & \multicolumn{1}{c}{ Interpretation } \\
\hline $\mathrm{X} \leq 64 \%$ & Very Poor \\
$64 \%<\mathrm{X} \leq 71 \%$ & Poor \\
$71 \%<\mathrm{X} \leq 77 \%$ & Cause for concern \\
$77 \%<\mathrm{X} \leq 80 \%$ & Borderline \\
$80 \%<\mathrm{X} \leq 84 \%$ & Good \\
$84 \%<\mathrm{X} \leq 87 \%$ & Very Good \\
$87 \% \geq \mathrm{X}$ & Excellent \\
\hline
\end{tabular}

Source: Customer Satisfaction Measurement: satisfaction index. www leadershipfactor.com

\section{Results and Discussion}

Testing the validity and reliability of the soft skills and hard skills questionnaires in this study using SPSS software tools. The validity test shows that the entire $r$-count value for each question item is greater than the r-table $\mathrm{df}=$ $40-2$ with a $5 \%$ significance of 0.3120 . These results indicate that all indicators used in this study are valid.

After testing the validity, the next step is to test the reliability which aims to determine the relationship with the problem of accuracy of data. Reliability test is used to determine the consistency of a measuring instrument, whether the measurement tool used is reliable and remains consistent if the measurement is repeated, a constructor variable is said to be reliable if it has an alpha above 0.60 (Ghozali, 2006)

Based on reliability calculations using SPSS software tools, it shows that all constructs or questions that have been prepared in the questionnaire are found that to measure the level of expectation (importance) and performance (performance) of Industrial Internships students obtained Alpha Cronbach on the soft skills questionnaire of 0.824 and hard skills of 0.758 . These results indicate that the 
questionnaire that has been compiled if repeated on the same respondent at relatively different times, the respondent's answer will be consistent (reliable).

Measurement Results Importance and Performance Analysis (IPA)

After processing the validity and reliability of the questionnaire data, the next step is to determine the value of satisfaction where $<0$ is negative satisfaction which indicates a gap between importance and performance, on the other hand, if satisfaction is positive $0>$ indicates the quality of Industrial Internship students exceeds the level of industry/company/internship satisfaction. Meanwhile, if $0=$ then the quality of Industrial Internship students have met expectations. The first stage in the Importance and Performance Analysis (IPA) is to determine the Level of Conformity between the level of interest in the industry/company/internship with the quality level of Industrial Internship students.

Table 2. Level of Conformity of Interest with Soft Skill Quality

\begin{tabular}{|c|c|c|c|c|c|c|c|}
\hline $\begin{array}{c}\text { SOFT SKILL } \\
\text { ATTRIBUTES }\end{array}$ & CODE & $\begin{array}{c}\text { SCORE } \\
\text { IMPORTAN } \\
\text { CE }(X i)\end{array}$ & $\begin{array}{c}\text { SCORE } \\
\text { IMPORTANCE } \\
\overline{X i}\end{array}$ & $\begin{array}{c}\text { SCORE } \\
\text { PERFORMAN } \\
\text { CE }(\mathrm{Y} i)\end{array}$ & $\begin{array}{c}\text { SCORE } \\
\text { PERFORMANCE } \\
\overline{Y i}\end{array}$ & $\begin{array}{c}\text { Level of } \\
\text { Conformity } \\
(\%)\end{array}$ & GAP \\
\hline Confident & IM. SS 1 & 685 & 6,23 & 698 & 6,35 & 101,90 & 0,12 \\
\hline Accuracy & IM. SS 2 & 650 & 5,91 & 632 & 5,75 & 97,23 & $-0,16$ \\
\hline $\begin{array}{l}\text { Ability to receive } \\
\text { feedback } \\
\text { (advice) }\end{array}$ & IM. SS 3 & 694 & 6,31 & 685 & 6,23 & 98,70 & $-0,08$ \\
\hline Motivation & IM. SS 4 & 681 & 6,19 & 663 & 6,03 & 97,36 & $-0,16$ \\
\hline $\begin{array}{l}\text { Ability to be } \\
\text { mature }\end{array}$ & IM. SS 5 & 680 & 6,18 & 656 & 5,96 & 96,47 & $-0,22$ \\
\hline Adaptability & IM. SS 6 & 683 & 6,21 & 671 & 6,10 & 98,24 & $-0,11$ \\
\hline Discipline & IM. SS 7 & 719 & 6,54 & 677 & 6,15 & 94,16 & $-0,38$ \\
\hline Honesty & IM. SS 8 & 722 & 6,56 & 710 & 6,45 & 98,34 & $-0,11$ \\
\hline $\begin{array}{l}\text { Have a } \\
\text { willingness to } \\
\text { learn }\end{array}$ & IM. SS 9 & 715 & 6,50 & 694 & 6,31 & 97,06 & $-0,19$ \\
\hline $\begin{array}{l}\text { Conformity Level } \\
\text { of all attributes }\end{array}$ & $\begin{array}{l}\text { Average } \\
\overline{\bar{X}}\end{array}$ & 6229 & $\begin{array}{c}56,63 \\
6,29 \\
\end{array}$ & 6086 & $\begin{array}{c}55,33 \\
6,15\end{array}$ & 97,70 & $-1,30$ \\
\hline
\end{tabular}


Table 3. Conformity of Interest with Hard Skill Quality

\begin{tabular}{|c|c|c|c|c|c|c|c|}
\hline $\begin{array}{c}\text { ATRIBUT } \\
\text { HARD SKILL }\end{array}$ & CODE & $\begin{array}{c}\text { SCORE } \\
\text { IMPORTANCE } \\
(\mathrm{X} i)\end{array}$ & $\begin{array}{c}\text { SCORE } \\
\text { IMPORTANCE } \\
\overline{X i}\end{array}$ & $\begin{array}{c}\text { SCORE } \\
\text { PERFORMANCE } \\
(\mathrm{Y} i)\end{array}$ & $\begin{array}{c}\text { SCORE } \\
\text { PERFORMANCE } \\
\overline{Y i}\end{array}$ & $\begin{array}{c}\text { Level of } \\
\text { Conformity } \\
(\%)\end{array}$ & GAP \\
\hline $\begin{array}{l}\text { Proficient in } \\
\text { using work } \\
\text { tools }\end{array}$ & IM. HS 1 & 643 & 5,85 & 649 & 5,90 & 100,93 & 0,05 \\
\hline $\begin{array}{l}\text { Proficient in } \\
\text { caring for work } \\
\text { tools }\end{array}$ & IM. HS 2 & 649 & 5,90 & 667 & 6,06 & 102,77 & 0,16 \\
\hline $\begin{array}{l}\text { Able to carry } \\
\text { out work } \\
\text { procedures or } \\
\text { orders }\end{array}$ & IM. HS 3 & 671 & 6,10 & 667 & 6,06 & 99,40 & $-0,04$ \\
\hline $\begin{array}{l}\text { Ability to } \\
\text { communicate } \\
\text { in the field of } \\
\text { engineering }\end{array}$ & IM. HS 4 & 676 & 6,15 & 654 & 5,95 & 96,75 & $-0,20$ \\
\hline $\begin{array}{l}\text { Have } \\
\text { knowledge of } \\
\text { electronic/elect } \\
\text { rical } \\
\text { engineering }\end{array}$ & IM. HS 5 & 659 & 5,99 & 641 & 5,83 & 97,27 & $-0,16$ \\
\hline $\begin{array}{l}\text { Speed of using } \\
\text { new work tools }\end{array}$ & IM. HS 6 & 634 & 5,76 & 670 & 6,09 & 105,68 & 0,33 \\
\hline $\begin{array}{l}\text { Ability to } \\
\text { provide } \\
\text { opinions or } \\
\text { answers in the } \\
\text { field of } \\
\text { Electronic/Elec } \\
\text { trical } \\
\text { Engineering }\end{array}$ & IM. HS 7 & 648 & 5,89 & 679 & 6,17 & 104,78 & 0,28 \\
\hline $\begin{array}{l}\text { Conformity Level } \\
\text { all attributes } \overline{\bar{X}}\end{array}$ & $\begin{array}{c}\text { verage of } \\
\overline{\bar{Y}}\end{array}$ & 4580 & $\begin{array}{r}1,64 \\
5,95 \\
\end{array}$ & 4627 & $\begin{array}{l}42,06 \\
6,01 \\
\end{array}$ & 101,03 & $\mathbf{0 , 4 3}$ \\
\hline
\end{tabular}

Source: Primary data, 2021

In table 2 shows the calculation of the soft skill gap, there is only one attribute that has positive satisfaction, namely the attribute "Confidence" while the other eight attributes get a negative perception of satisfaction so that the overall quality of soft skills shown by Industrial Internship students is still below the expectations of the parties. industries/companies where students carry out Industrial Internships with a gap level of -1.30 . While in table 3 the calculation of the Hard Skill gap four attributes have positive satisfaction, namely the attributes of "Proficient in using work tools", "Proficient in caring for work tools", "Learning speed", "Learning speed using new work tools", and "Ability to provide opinion or answer in the field of Electronic/Electrical Engineering" while the 
three attributes received a negative perception of satisfaction, the overall quality of the Industrial Internship students' hard skills received positive attention from the industry/company with a gap level of 0.43 .

For the Soft Skill Conformity Level, the total of all attributes between importance and performance is $97.70 \%$ which shows the level of soft skill suitability shown by Industrial Internship students is below the expectations of the company/industry where the Industrial Internship is held. While the total Hard Skills from the company/industry importance attribute and student performance in carrying out Industrial Internships is $101.03 \%$, this shows that the hard skills shown by Industrial Internship students have a perception above the expectations of the company/industry where students carry out industrial internships.

\section{Cartesian Soft Skill and Hard Skill Diagram}

After knowing the results of the, then the next step is to describe each attribute of soft skills and hard skills into a Cartesian diagram. The purpose of using this diagram is to see in detail the attributes that need improvement (Ikhtiagung \& Puspitasari, 2017). In table 2 the average score of the importance of soft skills for each attribute is 56.63 and the performance attribute is 53.33. In table 3 where the average importance hard skill score on each attribute is 41.64 and the performance attribute is 42.06. Meanwhile, the total average score of all importance-performance soft skills and hard skills consists of 6.29 and 6.01 respectively for soft skills, while the hard skills of 5.95 and 6.01 are used for the limits in the Cartesian diagram. SPSS software is used to describe each attribute into a Cartesian diagram, while the distribution of each soft skill and hard skill attribute into each quadrant can be seen in the image below. 


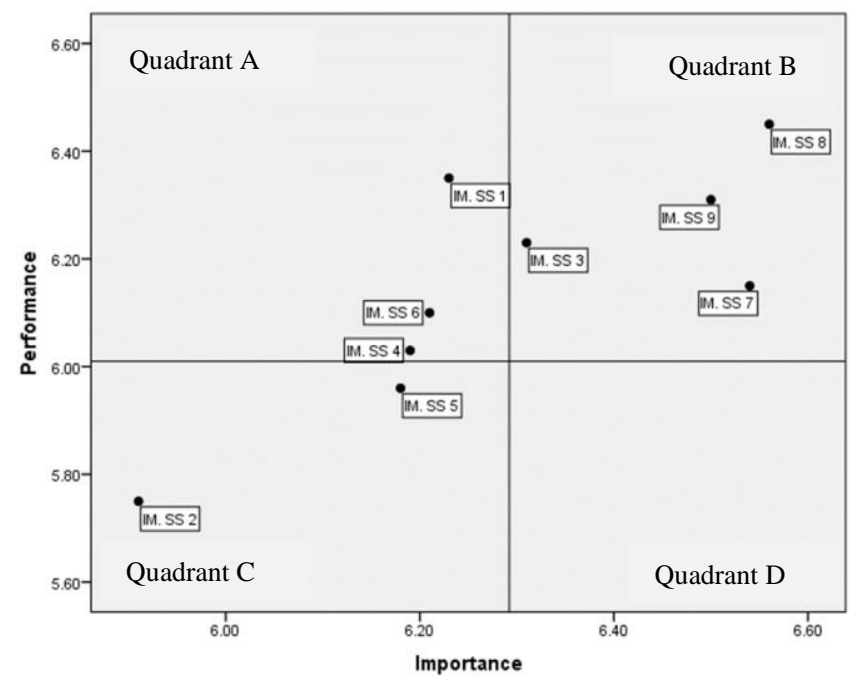

Figure 1. Cartesian Soft Skill Diagram

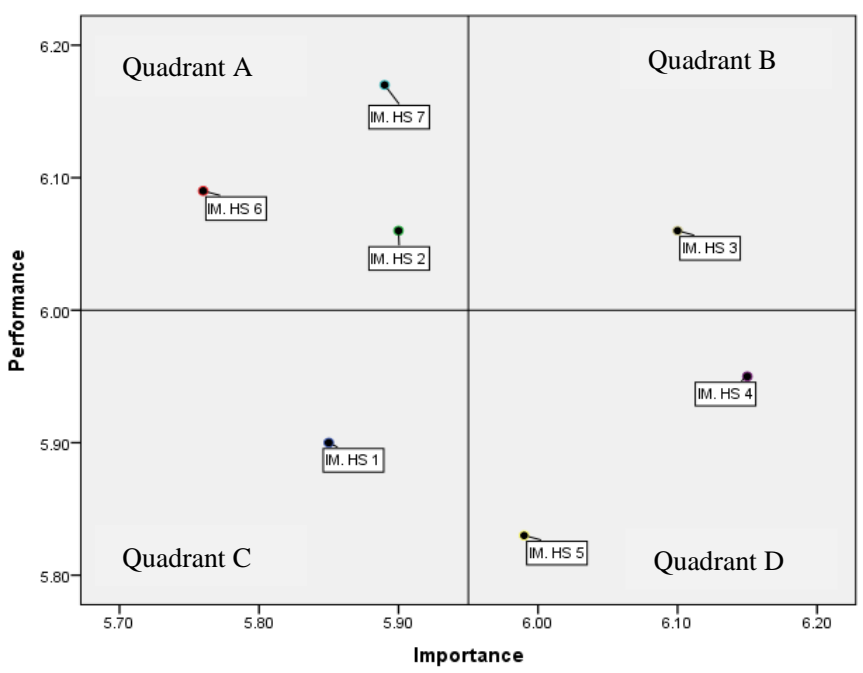

Figure 2. Cartesian Hard Skill Diagram

From the results of mapping soft skills and hard skills on industrial internship students using a Cartesian diagram, it can be seen that several attributes need to be improved and several attributes need to be maintained from the education system in the Department of Electronics Engineering. The results of the mapping in the Catersius Diagram in Figures 1 and 2 above are divided into four quadrants consisting of quadrants $\mathrm{A}, \mathrm{B}, \mathrm{C}$, and $\mathrm{D}$ which correspond to the level of 
compatibility between the importance of the company/industry and student performance in carrying out Industrial Internships. The results of mapping with a Cartesian diagram are as follows:

Quadrant A. This quadrant is an area that contains attributes that are considered important by the company/industry where the Industrial Internship is located, in this case, the Department of Electronics Engineering needs to make improvements to increase the company/industry's expectations of the quality of Industrial Internship students. In this quadrant, it is known that the attributes of soft skills and hard skills that are included in this quadrant include attributes, soft skills: self-confidence, motivation, and adaptability. Hard Skills: Proficient in maintaining work tools, Speed of learning to use new work tools, and Ability to provide opinions or answers in the field of Electronic/Electrical Engineering. Based on the results in Quadrant A, the Department of Electronics Engineering needs to concentrate on allocating resources to improve the performance included in this quadrant.

Quadrant B. It is an area that contains attributes that are considered important by the company/industry where the internship is located, and the attributes in quadrant B are considered the performance/quality shown by the students in the Industrial Internship that is following the wishes of the company/industry so that the level of satisfaction is relatively higher. For this reason, the attributes that are in the B quadrant need to be maintained by the Department of Electronic Engineering because students can show the quality of soft skills and hard skills. The attributes in this area include soft skills: Able to carry out work procedures or orders, Discipline, Honesty, and Have a willingness to learn. Hard skill: Able to carry out work procedures or orders. In quadrant B, there is only one hard skill attribute that is considered good performance/quality of students by the company/industry, for that the Department of Electronics Engineering needs strategic steps to improve the hard skills of students in quadrant A such as improving the quality of learning in Eyes Maintenance and Repair Lecture.

Quadrant C. Is an area that contains attributes that are considered less important for the company/industry but in reality, the performance of Industrial Internship students is considered unsatisfactory. However, the attributes in quadrant $\mathrm{C}$ do not rule out the possibility that in the future it will become an important concern for companies/industry, so the Department of Electronics Engineering needs to consider the attributes in quadrant $\mathrm{C}$. The attributes contained in quadrant $\mathrm{C}$ include soft skills: Accuracy and ability to be mature, while hard skill: Proficient in using work tools. The results of proficient attributes using hard skill work tools in quadrant $\mathrm{C}$ can be explained in the open questions in the questionnaire, where the 
company/industry where the Industrial Internship considers that the work tools contained in the Electronic Engineering Department are different from the production work tools in the company/industry so that before carrying out student work given briefing/training on operating machinery/production equipment, but on the other hand, based on the results of the 2021 Industrial Internship report held at PT. Kharisma Dua Putri found that as many as 8 students who carried out Industrial Internships were only placed as helpers.

Quadrant D. This quadrant is an area that is considered not too important and is not considered important by the company/industry so that the Department of Electronics Engineering focuses more or prioritizes its resources to deal with the problem of attributes in quadrant A. Based on the Cartesian diagram of soft skills, there is no single attribute. which are in the $\mathrm{C}$ quadrant so that the soft skill attributes in this study are considered important by the company/industry, while the hard skill attributes in the $\mathrm{D}$ quadrant area are the ability to communicate in the engineering field and have engineering knowledge.

\section{Measurement of Customer Satisfaction Index (CSI)}

After knowing the distribution of soft skill and hard skill attributes in the Cartesian diagram, the next step is to calculate the Customer Satisfaction Index (CSI) value. Based on tables 4 and 5 it is known that the CSI value obtained by soft skills is $68.36 \%$, which means that the satisfaction index of Industrial Internship students is in the weak or poor criteria, while the CSI value for hard skills is $85.83 \%$ which indicates that the quality of the hard skills shown Industrial Internship students have very good criteria or very good criteria.

Table 4. Customer Satisfaction Index (CSI) Soft Skill

\begin{tabular}{|c|c|c|c|c|c|c|}
\hline NO & $\begin{array}{l}\text { SOFT SKILL } \\
\text { ATTRIBUTES }\end{array}$ & CODE & $\begin{array}{l}\text { Average Interest } \\
\text { Score (AISc) }\end{array}$ & $\begin{array}{c}\text { Weighting Factor } \\
\left(\mathrm{WF}=\mathrm{AISc} / \sum \mathrm{AISc}\right)\end{array}$ & $\begin{array}{c}\text { Average } \\
\text { Satisfaction } \\
\text { Score (ASSc) }\end{array}$ & $\begin{array}{c}\text { Weighted Score } \\
\text { (WS=ASSc } \mathrm{x} \\
\text { WF) }\end{array}$ \\
\hline 1 & Confident & IM. SS 1 & 6,23 & 0,110 & 6,35 & 0,70 \\
\hline 2 & Accuracy & IM. SS 2 & 5,91 & 0,104 & 5,75 & 0,60 \\
\hline 3 & $\begin{array}{l}\text { Ability to receive } \\
\text { feedback (advice) }\end{array}$ & IM. SS 3 & 6,31 & 0,111 & 6,23 & 0,69 \\
\hline 4 & Motivation & IM. SS 4 & 6,19 & 0,109 & 6,03 & 0,66 \\
\hline 5 & Ability to be mature & IM. SS 5 & 6,18 & 0,109 & 5,96 & 0,65 \\
\hline 6 & Adaptability & IM. SS 6 & 6,21 & 0,110 & 6,10 & 0,67 \\
\hline 7 & Discipline & IM. SS 7 & 6,54 & 0,115 & 6,15 & 0,71 \\
\hline 8 & Honesty & IM. SS 8 & 6,56 & 0,116 & 6,45 & 0,75 \\
\hline
\end{tabular}




\begin{tabular}{|c|c|c|c|c|c|c|}
\hline NO & $\begin{array}{c}\text { SOFT SKILL } \\
\text { ATTRIBUTES }\end{array}$ & CODE & $\begin{array}{l}\text { Average Interest } \\
\text { Score (AISc) }\end{array}$ & $\begin{array}{c}\text { Weighting Factor } \\
\left(\mathrm{WF}=\mathrm{AISc} / \sum \mathrm{AISc}\right)\end{array}$ & $\begin{array}{c}\text { Average } \\
\text { Satisfaction } \\
\text { Score (ASSc) }\end{array}$ & $\begin{array}{c}\text { Weighted Score } \\
\text { (WS=ASSc } \mathrm{x} \\
\text { WF) }\end{array}$ \\
\hline \multirow[t]{2}{*}{9} & $\begin{array}{l}\text { Have a willingness to } \\
\text { learn }\end{array}$ & IM. SS 9 & 6,50 & 0,115 & 6,31 & 0,72 \\
\hline & \multicolumn{2}{|l|}{ TOTAL } & 56,63 & \multicolumn{3}{|c|}{55,33} \\
\hline \multicolumn{3}{|c|}{ Weighted Total (WT) } & & \multicolumn{3}{|r|}{6,15} \\
\hline \multicolumn{3}{|c|}{ Customer Satisfaction Index (CSI) } & & \multicolumn{2}{|c|}{$(6,15: 9) \times 100 \%=$} & 68,36 \\
\hline
\end{tabular}

Table 5. Customer Satisfaction Index (CSI) Hard Skill

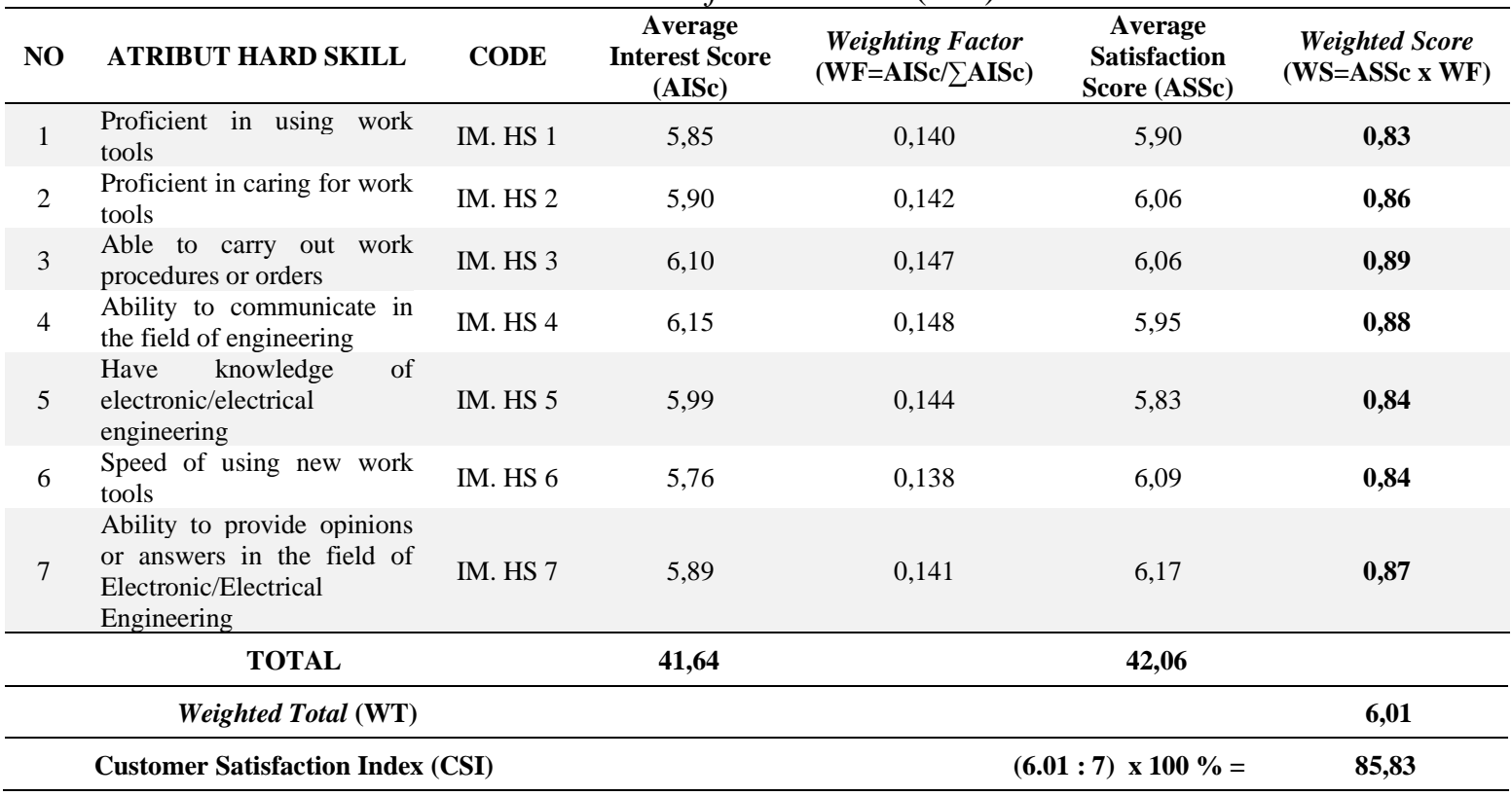

Source: Primary data, 2021

\section{Conclusion}

The implications of the results of the Importance Performance Analysis and Customer Satisfaction Index research from mapping the soft skills and hard skills of Industrial Engineering students at the Department of Electronics Engineering can be concluded that the attributes contained in quadrant A consist of soft skills: self-confidence, motivation, and adaptability. And hard skills: Proficient in caring for work tools, Speed of learning to use new work tools, and Ability to provide opinions or answers in the field of Electronic/Electrical Engineering, are attributes 
that need to be considered by the Electronics Engineering department to maintain company/industry trust to continue to accept the Industrial Internship program. As a vocational-based education, Industrial Workshop is a means for students to gain work experience while understanding the organizational environment within a company/industry along with solving problems that exist within the company/industry.

\section{Acknowledgment}

This acknowledgment is addressed to students of Electronic Engineering and Electrical Engineering who have been willing to fill out the questionnaire and to all those who have helped and participated in this research.

\section{References}

Aritonang, R. L. (2005). Kepuasan Pelanggan [Customer satisfaction]. Jakarta: Gramedia.

Ariwibowo, \& Sailah, I. (2008). Pengembangan Soft Skill di Perguruan Tinggi [Soft Skill Development in Higher Education]. Jakarta: Direktorat Jenderal Pendidikan Tinggi.

Asbari, M., Wijayanti, L. M., Hyun, C. C., Imelda, D., Yanthy, E., \& Purwanto, A. (2020). Hard Skill atau Soft Skill: Manakah Yang Lebih Penting Bagi Inovasi Guru [Hard Skills or Soft Skills: Which Is More Important For Teacher Innovation]. Edumaspul: Jurnal Pendidikan, 4(1), 1-20. doi:10.33487/edumaspul.v4i1.333

Direktorat Akademik. (2008). Pengembangan Soft Skill dalam Proses Belajar di Perguruan Tinggi [Soft Skill Development in the Learning Process in Higher Education]. Jakarta: Direktorat Akademik, Direktorat Jenderal Pendidikan Tinggi Departemen Pendidikan Nasional.

Elfindri, Rasmita, F., Engel, R. B., Rumengan, J., Wello, M. B., Tobing, P., Eriyani, E. (2011). Soft Skill: Untuk Pendidikan [Soft Skill: For Education]. Jakarta: Baduose Media.

Ghozali, I. (2005). Aplikasi Analisis Multivariate dengan Program SPSS [Multivariate Analysis Application with SPSS Program]. Semarang: Universitas Diponegoro. 
Ikhtiagung, G. N., \& Puspitasari, E. D. (2017). Measuring Students Satisfaction Toward State Polytechnic of Cilacap Sevice Quality (SERVQUAL) Whit Importance Performance Analysis Method. Probisnis, 10(1), 81-98.

Illah, S. (2008). Pengembangan Soft Skill di Perguruan Tinggi [Soft Skill Development in Higher Education]. Jakarta: Direktorat Jenderal Perguruan Tinggi.

Kemendikbud. (2021). Revisi Rencana Strategis Direktorat Jenderal Perndidikan Menengah 2010-2014 [Revision of the Strategic Plan of the Directorate General of Secondary Education 2010-2014]. Jakarta: Kemendikbud.

Patacsil, F. F., \& Tablatin, C. S. (2017). Exploring The Importance of Soft And Hard Skill As Perceived By IT Internship Students And Industry: A GAP Analysis. Journal of Technology and Science Education, 7(3), 347-368.

Politeknik Negeri Cilacap. (2017). Pedoman Magang Industri [Industry Internship Guidelines]. Cilacap: PNC.

Priyono, A. H., Widagdo, S., \& Handayani, Y. I. (2021). The Effect of Hard Skill and Soft Skill Competency on Improving the Quality of Services in Public Services Malls at Banyuwangi Regency. International Journal of Innovative Science and Research Technology, 6(9), 325 - 329.

Ronnie, M. D. (2006). The Power of Emotional and Adversity Quotient For Teachers. Jakarta: Hikmah (Mizan Publika).

Singarimbun, M., \& Effendi, S. (1987). Metode Penelitian Survei [Survey Research Method]. Yogyakarta: LP3E Universitas Gadjah Mada.

Widayanti, R. (2012). Pengaruh Hard Skill dan Soft Skill Terhadap Kinerja Karyawan (Studi Pada PT. Telkom Kandatel Malang [The Influence of Hard Skills and Soft Skills on Employee Performance (Study at PT. Telkom Kandatel Malang]. Jurnal Dinamika Dotcom, 3(2), 62-64.

Yola, M., \& Budianto, D. (2013). Analisis Kepuasan Konsumen Terhadap Kualitas Pelayanan Dan Harga Produk Pada Supermarket Dengan Menggunakan Metode Importance Performance Analysis (IPA) [Analysis of Consumer Satisfaction on Service Quality and Product Prices at Supermarkets Using the Importance Performance Analysis (IPA) Method]. Jurnal Optimasi Sistem Industri, 12(12), 301-309. 
Zhao, Y., \& Wang, H. (2020). Influencing Factors of Choosing Modern Apprenticeship Program for Higher Vocational College Students-Taking E-commerce Major of A University as an Example. 6th International Conference on Social Science and Higher Education (ICSSHE 2020). 505, hal. 753-759. Xiamen, China: Atlantis Press SARL. doi: $10.1177 / 00207209211003212$

Zulkifli, R., Tewal, B., \& Kojo, C. (2018). Pengaruh Hard Dan Soft Skill Terhadap Kinerja Karyawan Perum Damri Manado [The Influence of Hard and Soft Skills on Employee Performance at Perum Damri Manado]. Jurnal EMBA, 6(2), 1008-1017. 